\title{
Pengaruh Latihan Icky Shuffle dan Hop Scotch terhadap Peningkatan Kelincahan dan Power Otot Tungkai
}

\author{
Hary Septianwari, Nurkholis, dan Wijono \\ Program Studi Pendidikan Olahraga, Pascasarjana Universitas Negeri Surabaya \\ Email: septianwari@hamzanwadi.ac.id
}

\begin{abstract}
Abstrak. Penelitian ini bertujuan untuk mengeksplorasi pengaruh latihan icky shuffle dan hop scotch terhadap peningkatan kelincahan (agility) dan power otot tungkai. Penelitian ini menggunakan pendekatan penelitian kuantitatif. Jenis penelitian yang digunakan tergolong penelitian eksperimen. Desain penelitian ini menggunakan eksperimen semu (quasi experimental) dengan rancangan penelitian menggunakan matching-only design. Subjek penelitian sebagai sampel sebanyak 45 orang siswa di SMA Negeri 5 Mataram. Selanjutnya dilakukan pengelompokan pada sampel penelitian, dimana kelompok eksperimen 1 yakni kelompok icky shuffle $\left(\mathrm{X}_{1}\right)$, kelompok eksperimen 2 yakni kelompok hop scotch $\left(\mathrm{X}_{2}\right)$, dan kelompok kontrol. Penentuan anggota sampel menggunakan metode ordinal pairing, agar diperoleh susunan berdasarkan jenjang dalam atribut tertentu. Jenis data yang dikumpulkan dalam penelitian ini adalah tes kelincahan (agility) dan power otot tungkai dari kedua bentuk latihan masing-masing kelompok. Hasil tes dicatat dan dihitung berdasarkan kelompok dan bentuk latihan yang dilakukankan. Uji normalitas, homogenitas, dan uji hipotesis dilakukan dimana analisis data menggunakan teknik statistik deskriptif dan dianalisis dengan bantuan SPSS versi 20.0. Hasil penelitian menunjukkan bahwa; a) terdapat pengaruh yang signifikan latihan Icky Shuffle terhadap peningkatan kelincahan dan power otot tungkai, b) terdapat pengaruh yang signifikan latihan Hop Scotch terhadap peningkatan kelincahan dan power otot tungkai, dan c) terdapat perbedaan pengaruh yang signifikan antara latihan Icky Shuffle dan Hop Scotch terhadap peningkatan kelincahan dan power otot tungkai.
\end{abstract}

Kata kunci: Latihan Icky Shuffle, Hop Scotch, Kelincahan (Agility), Power Otot Tungkai

\section{PENDAHULUAN}

Kondisi fisik yang prima merupakan faktor yang sangat diperlukan oleh setiap atlet untuk mencapai prestasi. Tanpa persiapan kondisi fisik yang memadai, maka atlet khususnya atlet pemula akan sangat kesulitan untuk mengembangkan teknik, taktik dalam kegiatan olahraga. Kondisi fisik merupakan syarat yang sangat diperlukan dalam peningkatan prestasi seorang atlet, bahkan dapat dikatakan sebagai landasan utama untuk pencapaian prestasi setinggi-tingginya. Kondisi fisik dapat dicapai dengan latihan yang teratur dan terencana dengan baik, serta disesuaikan dengan sasaran yang ingin dicapai. Latihan adalah proses penyempurnaan kualitas atlet secara sadar untuk mencapai prestasi maksimal dengan diberi beban fisik dan mental secara teratur, terarah, bertahap, meningkat, dan berulangulang (Roesdiyanto \& Budiwanto, 2008). Pemilihan bentuk latihan harus sesuai dengan komponen biomotorik yang ingin ditingkatkan. Selain itu dalam upaya peningkatan kinerja, sebaiknya menggunakan program latihan yang tepat secara prinsip dan teori.
Pengembangan latihan fisik pada setiap program latihan dilakukan melalui tahapan fisik umum, persiapan fisik khusus dan membangun tingkat kemampuan biomotorik yang tinggi (Bompa, 2009). Komponen kondisi fisik pada cabang olahraga banyak menggunakan aktivitas jasmani secara dinamis pada umumnya tidak jauh berbeda, komponen tersebut merupakan komponen biomotor yang saling berkaitan untuk membentuk kondisi fisik yang baik. Kemampuan komponen kondisi fisik yang harus dimiliki seorang pemain atau atlet untuk mencapai kondisi puncaknya yakni: daya tahan, kekuatan, kecepatan, kelincahan, daya ledak, kelenturan, ketepatan, koordinasi, keseimbangan, reaksi (Harsono, 2015). Dari sepuluh komponen biomotor tersebut, tidak semuanya harus dimiliki secara baik, mengingat olahraga futsal memiliki karakteristik sendiri yakni pergerakan kaki yang dinamis, maka komponen yang dominan harus dimiliki pemain futsal adalah kelincahan dan power otot tungkai.

Kelincahan merupakan kemampuan untuk bergerak merubah arah dan posisi dengan cepat dan tepat hingga memberikan 
kemungkinan seseorang untuk melakukan gerakan ke arah yang berlawanan dan mengatasi situasi yang dihadapi lebih cepat dan lebih efisien. Umumnya, kelincahan dapat didefinisikan sebagai kemampuan untuk memulai langkah eksplosif, mungurangi kecepatan, perubahan arah, dan mempercepat lari dengan mempertahankan kontrol tubuh dan meminimalkan penurunan kecepatan (Sethu, 2014). Hal ini senada juga diungkapkan Sucharitha (2014) kelincahan adalah kemampuan untuk mempertahankan atau mengontrol posisi tubuh saat berubah arah selama serangkaian gerakan.

Dalam olahraga, power merupakan komponen kondisi fisik yang penting, karena komponen tersebut memberi banyak dukungan dari setiap pergerakan pemain dilapangan. Eksplosif Power adalah penentu utama kinerja dalam kegiatan yang membutuhkan urutan satu gerakan untuk menghasilkan kecepatan tinggi saat dirilis, tindakan daya ledak otot yang dimaksud seperti dalam melempar, melompat dan aksi reaksi (Suresh \& Perinbaraj, 2016). Power merupakan salah satu komponen kondisi fisik yang identik dengan kekuatan eksplosif (explosive power). Daya ledak adalah salah satu faktor yang penting bagi keterampilan atlet, yang memungkinkan mereka untuk mencapai kecepatan tendangan yang maksimal saat bermain (Taheri, 2014). Berdasarkan bagan komponen biomotor, daya ledak terdiri dari komponen kekuatan maksimum dan kecepatan maksimum (Bompa. 2015). Melihat unsur kondisi fisik tersebut, kelincahan dan power merupakan unsur kondisi fisik yang diperlukan di dalam banyak cabang olahraga (Gamble, 2012). Misalnya cabang olahraga sepakbola, pencak silat, futsal, dan atletik, disamping itu kelincahan dan power ini mempunyai peranan yang sangat penting untuk meningkatkan prestasi dalam bidang olahraga.

Tujuan dari latihan adalah untuk meningkatkan kemampuan untuk melakukan aktivitas maksimal. Dalam pernyataan tersebut jelas bahwa olahraga futsal membutuhkan kondisi fisik yang kompleks. Untuk mencapai kondisi fisik tersebut seorang pelatih harus membuat program latihan dan metode latihan yang baik, agar efektifitas latihan dan tujuan latihan dapat tercapai secara bersamaan dan sesuai dengan kebutuhan kondisi fisik dalam olahraga tersebut. Untuk pencapaian prestasi yang maksimal, seorang atlet harus memiliki kondisi fisik yang mendukung, yang dilatih menggunakan latihan yang sistematis.

Ada banyak bentuk latihan yang dipakai di era modern saat ini untuk meningkatkan komponen biomotorik atlet, contohnya seperti latihan menggunakan ladder drill. Ladder drill merupakan suatu bentuk alat latihan yang menyerupai anak tangga yang berupa tali dan diletakkan di lantai, dengan cara pemakaian menggunakan satu atau dua kaki. Tangga latihan bermanfaat bagi atlet untuk bergerak cepat dengan menggunakan metode latihan yang disengaja. Hal ini penting bagi para atlet dari setiap bentuk dan ukuran (Chandrakumar, 2015). Ladder drill memungkinkan pelatih dan pemain untuk menjadi imajinatif dan latihan ini juga dapat memberikan efek menyenangkan (Srinivasan, 2013). Ladder drill merupakan cara terbaik untuk menigkatkan kecepatan, kelincahan, kordinasi dan kecepatan secara kesuluruhan, dan latihan ini tidak dimaksudkan untuk mengalami kelelahan berarti atau mengalami sesak nafas (Rajendran, 2016). Ambarukmi, dkk (2007) berpendapat bahwa sifat khusus beban latihan akan menghasilkan tanggapan khusus, untuk itu program latihan hendaknya dirancang khusus sesuai dengan cabang olahraga, peran olahraga, system energi, pola gerak, keterlibatan otot biomotor. Selaras dengan dengan hal tersebut, latihan dengan menggunakan ladder drill sangat tepat untuk cabang olahraga yang menuntut para atletnya untuk memiliki komponen biomotor dominan seperti kelincahan dan power. Ladder drill merupakan bentuk latihan yang cukup banyak dan beraneka ragam variasinya, akan tetapi dalam penelitian ini hanya menggunakan dua bentuk latihan yaitu icky shuffle dan hop scotch.

Berdasarkan pengamatan, gerakan dalam icky shuffle dan hop scotch mirip 
seperti gerakan kaki dalam olahraga futsal yang banyak digunakan pemain pada pola langkah dalam memposisikan diri untuk penguasaan bola dan langkah hindaran langsung. Perbedaan gerakan yang paling mendasar antara icky shuffle dan hop scotch yaitu penggunaan tungkai saat melakukan perpindahan atau perubahan arah. Pada icky shuffle gerakan perpindahan atau perubahan arah menggunakan satu tungkai secara bergantian, sedangkan pada hop scotch gerakan perpindahan atau perubahan arah menggunakan dua tungkai secara bersamaan. Menurut Brown dan Ferriggno (2005) bahwa latihan icky shuffle merupakan latihan yang dapat meningkatkan kelincahan, koordinasi, kecepatan, dan power dengan menggunakan ladder drill. Gerakan yang ditekankan pada saat latihan icky shuffle antara lain kelincahan, koordinasi dan tubuh bagian bawah seperti otot tungkai dan elastis pergelangan kaki. Adapun latihan hop scotch menurut Brown dan Ferriggno (2005) merupakan latihan yang dapat melatih kecepatan, koordinasi, kelincahan, dan power. Gerakan yang ditekankan pada latihan hop scotch antara lain koordinasi dan elastis pergelangan kaki.

Beberapa tahun belakangan ini, olahraga futsal sudah mulai dilakukan pada kegiatan ekstrakulikuler sekolah baik itu tingkat menengah dan tingkat atas. Di Nusa Tinggara Barat, khususnya Kota Mataram hampir setiap tahun mengadakan turnamen ataupun kejuaraan futsal tingkat SMA (Sekolah Menengah Atas) yang diikuti oleh berbagai sekolah yang ada. SMAN 5 Mataram adalah salah satu tim peserta yang secara rutin mengikuti turnamen futsal se-Kota Mataram. Berdasarkan hasil pengamatan di ekstrakulikuler futsal SMAN 5 Mataram, bahwa dalam sesi latihan hanya menerapkan latihan Teknik dengan menggunakan drilldrill yang mengarah ke skill dasar permainan futsal. Sementara bentuk latihan fisik untuk meningkatkan komponen biomotorik atlet futsal yang menunjang kinerja skill seperti kelincahan dan power jarang diberikan, sehingga para siswa yang mengikuti ekstrakulikuler futsal di SMAN 5 Mataram terkendala pada kemampuan fisiknya yang seharusnya hal itu membantu memaksimalkan kinerja skill dalam bermain dan prestasi mereka.

Penelitian ini bertujuan untuk mengeksplorasi pengaruh latihan icky shuffle dan hop scotch terhadap peningkatan kelincahan dan power otot tungkai. Penelitian ini secara teoritis diharapkan memberi manfaat sebagai landasan teori dan pedoman pembentukan program latihan yang bertujuan untuk meningkatkan kelincahan dan power otot tungkai sehingga dapat memberikan informasi untuk pelatih maupun pelaku olahraga dalam upaya menemukan formula yang paling tepat.

\section{METODE PENELITIAN}

Penelitian ini menggunakan pendekatan penelitian kuantitatif. Jenis penelitian yang digunakan tergolong penelitian eksperimen. Desain penelitian ini menggunakan eksperimen semu (quasi experimental) dengan rancangan penelitian menggunakan matching-only design seperti pada Gambar 1.

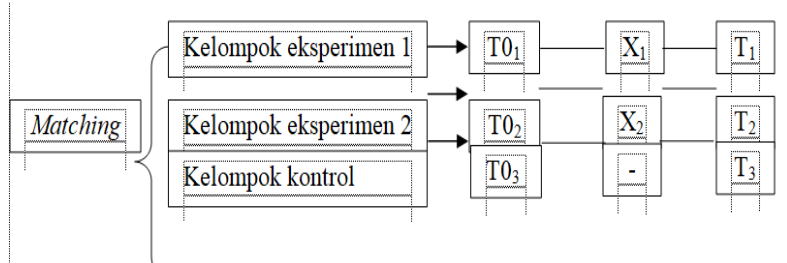

Gambar 1. Rancangan Penelitian

Keterangan:

\begin{tabular}{|c|c|}
\hline $\mathrm{T}_{1}$ & $\begin{array}{l}\text { : Matching. } \\
\text { : Pretest kelompok eksperimen kelincahan, } \\
\text { dan power otot tungkai. }\end{array}$ \\
\hline$\rho_{2}$ & $\begin{array}{l}\text { Pretest kelompok eksperimen kelincahan, } \\
\text { dan power otot tungkai. }\end{array}$ \\
\hline $\mathrm{O}_{3}$ & : Pretest kelompok kontrol. \\
\hline 1 & : Treatment kelompok eksperimen icky \\
\hline & : Treatment kelompok eksperimen hop \\
\hline & $\begin{array}{l}\text { Posttest kelompok eksperimen } \\
\text { kelincahan, dan power otot tungkai. }\end{array}$ \\
\hline & $\begin{array}{l}\text { Posttest kelompok eksperimen } \\
\text { kelincahan, dan } \text { power otot tungkai. }\end{array}$ \\
\hline & elompok kontrol. \\
\hline
\end{tabular}

Subjek penelitian diambil dari populasi, dan pembagian kelompok menggunakan pretest kelincahan dan power 
kemudian di $t$ score selanjutnya dikelompokan menggunakan ordinal pairing, kemudian dibagi menjadi 3 kelompok. Masing-masing kelompok dilakukan pretest yaitu kelompok eksperimen sebagai data $\left(\mathrm{TO}_{1}\right),\left(\mathrm{TO}_{2}\right)$ dan kelompok kontrol sebagai data $\left(\mathrm{TO}_{3}\right)$. Kelompok eksperimen 1 diberi perlakuan $\left(\mathrm{X}_{1}\right)$, yaitu latihan icky shuffle dan kelompok eksperimen 2 diberi perlakua $\left(\mathrm{X}_{2}\right)$, yaitu latihan hop scotch. Kelompok kontrol diberi program latihan kovensional, yaitu latihan yang dilakukan sesuai dengan program latihan biasanya. Setelah enam minggu latihan selanjutnya dilakukan post-test kepada ke tiga kelompok $\left(\mathrm{T}_{1}\right),\left(\mathrm{T}_{2}\right)$, dan $\left(\mathrm{T}_{3}\right)$.

Populasi dalam penelitian ini adalah keseluruhan dari siswa yang mengikuti ekstrakurikuler futsal di SMA Negeri 5 Mataram sebanyak 45 siswa dengan karakteristik berjenis kelamin laki-laki dan usia 15-17 tahun. Dalam penelitian ini menggunakan seluruh subjek penelitian berjumlah 45 orang, jadi penelitian ini termasuk kedalam penelitian populasi. Dengan kata lain sampel dari penelitian ini adalah merupakan keseluruhan dari subjek penelitian. Penentuan sampel dalam penelitian ini dilakukan sebelum pretest dikarenakan setiap anggota populasi memiliki peluang yang sama untuk terpilih menjadi anggota sampel. Kemudian dilakukan pembagian kelompok eksperimen 1 yakni kelompok icky shuffle $\left(\mathrm{X}_{1}\right)$, kelompok eksperimen 2 yakni kelompok hop scotch $\left(\mathrm{X}_{2}\right)$, dan kelompok kontrol. Penentuan anggota sampel menggunakan metode ordinal pairing, agar diperoleh susunan berdasarkan jenjang dalam atribut tertentu. Ordinal pairing merupakan salah satu cara untuk megelompokkan sampel dengan menggunakan sistem urutan yang menggambarkan adanya peringkat.

Jenis data yang akan dikumpulkan dalam penelitian ini adalah tes kelincahan dan power otot tungkai dari kedua bentuk latihan masing-masing kelompok. Kemudian hasil tes akan dicatat dan dihitung berdasarkan kelompok dan bentuk latihan yang dilakukankan. Uji normalitas, homogenitas, dan uji hipotesis dilakukan dimana analisis data menggunakan teknik statistik deskriptif dan dianalisis dengan bantuan program komputer SPSS (Statistical Program For Social Science) 20.0.

\section{HASIL DAN PEMBAHASAN}

Penelitian ini dilakukan dengan pengambilan skor sampel sebelum perlakuan (pre test) dan setelah perlakukan (post test). Terdapat tiga kelompok meliputi kelompok yang menggunakan jenis latihan icky shuffle (kelompok eksperimen 1), kelompok yang menggunakan jenis latihan hop scotch (kelompok eksperimen 2), dan kelompok kontrol. Berikut ini dijabarkan deskripsi data hasil penelitian berdasarkan aspek yang digunakan dalam penelitian.

Kelompok eksperimen 1 merupakan kelompok yang menggunakan icky shuffle sebagai program latihan dalam penelitian. Terdapat dua variabel yang diukur, yaitu kelincahan (agility) dan daya ledak (power). Pengambilan data dilakukan selama dua kali, yaitu sebelum perlakuan (pre test) dan setelah perlakuan (post test). Berikut ini dijabarkan deskripsi data pada kelompok eksperimen 1.

Tabel 1. Deskripsi Data Skor Kelompok Icky Shuffle pada Variabel pada Variabel Power dan Agility

\begin{tabular}{|l|l|c|c|c|c|c|c|}
\hline Variabel & Variabel & Mean & Median & Variance & $\begin{array}{c}\text { Std. } \\
\text { Deviation }\end{array}$ & Min & Max \\
\hline Power (watt) & Pre test & 878,19 & 893,05 & 13952,50 & 118,12 & 610,38 & 1085,11 \\
& Post Test & 908,42 & 923,01 & 13515,59 & 116,26 & 654,26 & 1134,23 \\
\hline \multirow{2}{*}{ Agility (detik) } & Pre test & 17,29 & 17,30 & 0,65 & 0,81 & 16,21 & 18,76 \\
\cline { 2 - 8 } & Post Test & 17,13 & 17,21 & 0,67 & 0,82 & 15,90 & 18,66 \\
\hline
\end{tabular}

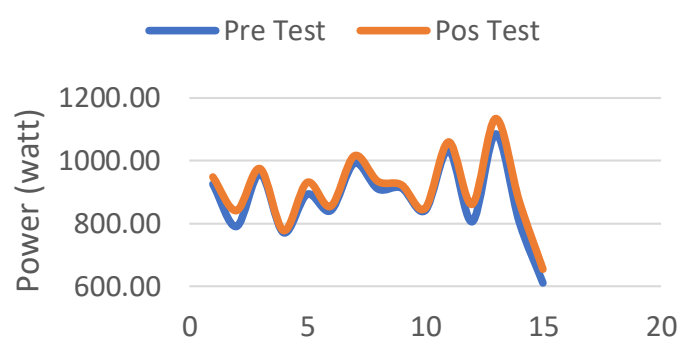

Gambar 2. Grafik perubahan power pada kelompok icky shuffle 


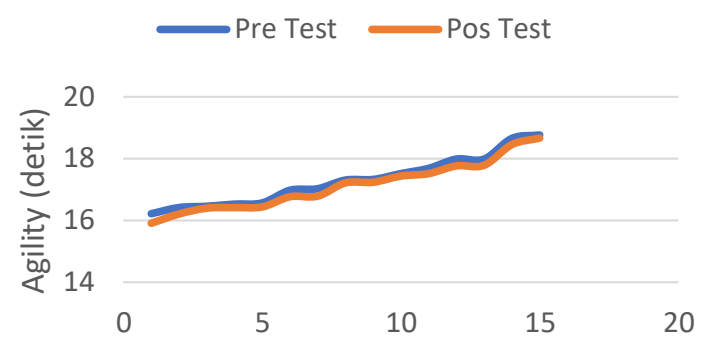

Gambar 3. Grafik perubahan agility pada kelompok icky shuffle

Kelompok eksperimen 2 merupakan kelompok yang menggunakan hop scotch sebagai program latihan dalam penelitian. Terdapat dua variabel yang diukur, yaitu kelincahan (agility) dan daya ledak (power). Pengambilan data dilakukan selama dua kali, yaitu sebelum perlakuan (pre test) dan setelah perlakuan (post test). Berikut ini dijabarkan deskripsi data pada kelompok eksperimen 2.

Tabel 2. Deskripsi Data Skor Kelompok Hop Scotch pada Variabel pada Variabel Power dan Agility

\begin{tabular}{|l|l|c|c|c|c|c|c|}
\hline Variabel & Variabel & Mean & Median & Variance & $\begin{array}{c}\text { Std. } \\
\text { Deviation }\end{array}$ & Min & Max \\
\hline Power & Pre test & 962,23 & 984,11 & 18150,10 & 134,72 & 713,36 & 1150,91 \\
\hline \begin{tabular}{l} 
(watt) \\
\cline { 1 - 8 } Agility
\end{tabular} & Post Test & 983,81 & 992,42 & 17989,25 & 134,12 & 747,51 & 1160,62 \\
\hline (detik) & Post Test & 17,36 & 17,25 & 0,90 & 0,95 & 16,22 & 19,55 \\
\hline
\end{tabular}

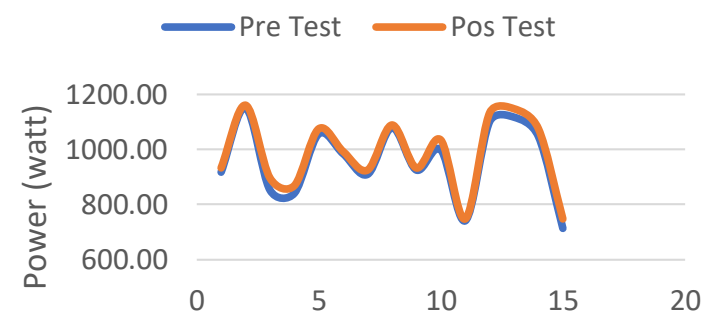

Gambar 4. Grafik perubahan power pada kelompok hop scotch

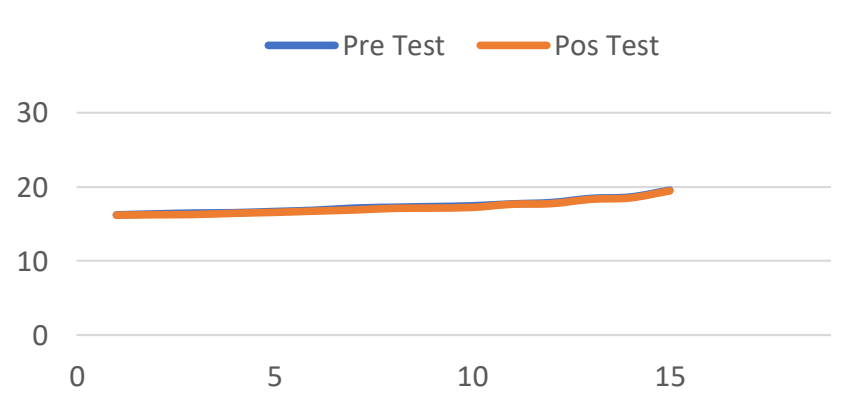

Gambar 5. Grafik perubahan agility pada kelompok hop scotch
Kelompok terakhir yang digunakan dalam penelitian adalah kelompok kontrol. Kelompok ini tidak mendapatkan program latihan khusus selama penelitian. Deskripsi dari data yang diperoleh dalam penelitian pada kelompok kontrol dijabarkan sebagai berikut.

Tabel 3. Deskripsi Data Skor Kelompok Kontrol pada Variabel pada Variabel Power dan Agility

\begin{tabular}{|r|l|c|c|c|c|c|c|}
\hline Variabel & Variabel & Mean & Median & Variance & $\begin{array}{c}\text { Std. } \\
\text { Deviation }\end{array}$ & Min & Max \\
\hline \multirow{2}{*}{ Power (watt) } & Pre test & 935,07 & 949,77 & 7874,58 & 88,74 & 786,95 & 1085,11 \\
& Post Test & 968,43 & 974,63 & 9398,41 & 96,95 & 800,63 & 1124,58 \\
\hline \multirow{2}{*}{ Agility (detik) } & Pre test & 17,29 & 17,30 & 0,65 & 0,81 & 16,21 & 18,76 \\
\cline { 2 - 8 } & Post Test & 17,29 & 17,17 & 0,94 & 0,97 & 16,14 & 19,67 \\
\hline
\end{tabular}

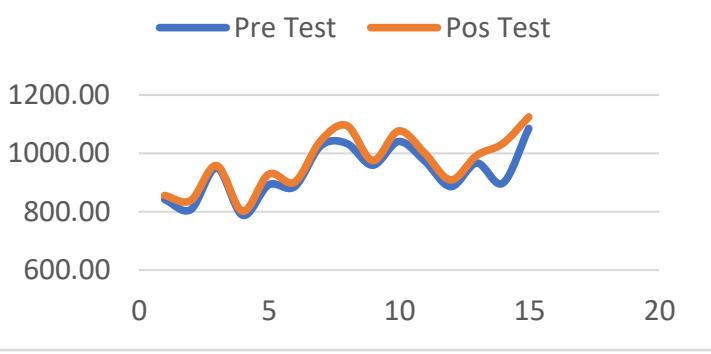

Gambar 6. Grafik perubahan power pada kelompok kontrol

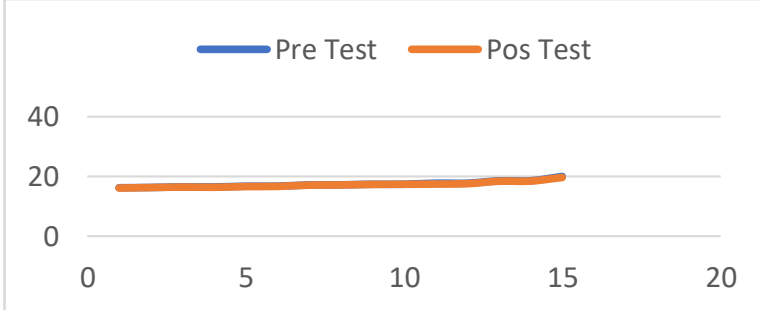

Gambar 7. Grafik perubahan agility pada kelompok kontrol

Penelitian ini menggunakan pengujian perbedaan pengaruh dari masing-masing program latihan yang diberikan. Sebelum melakukan pengujian hipotesis, dilakukan uji prasyarat berupa uji normalitas distribusi dan homogenitas variansi. Pengujian normalitas distribusi dilakukan untuk menguji apakah data berasar dari skor yang berdistribusi normal. Seluruh variabel dalam penelitian ini diuji dengan menggunakan shapiro wilk. Hasil pengujian ditunjukkan pada Tabel 4. 
Tabel 4. Hasil Pengujian Normalitas

Distribusi

\begin{tabular}{|c|c|c|c|c|c|}
\hline & \multirow{2}{*}{ Kelompok } & \multicolumn{3}{|c|}{ Shapiro-Wilk } & \multirow{2}{*}{ Ket } \\
\hline & & Statistic & $\mathrm{df}$ & Sig. & \\
\hline \multirow[t]{3}{*}{ Pretest power } & Kelompok Perlakuan 1 & 0,973 & 15 & 0,904 & Normal \\
\hline & Kelompok Perlakuan 2 & 0,951 & 15 & 0,540 & Normal \\
\hline & Kelompok Kontrol & 0,966 & 15 & 0,793 & Normal \\
\hline \multirow[t]{3}{*}{ Postes power } & Kelompok Perlakuan 1 & 0,975 & 15 & 0,924 & Normal \\
\hline & Kelompok Perlakuan 2 & 0,932 & 15 & 0,288 & Normal \\
\hline & Kelompok Kontrol & 0,978 & 15 & 0,954 & Normal \\
\hline \multirow[t]{3}{*}{ Pretes agility } & Kelompok Perlakuan 1 & 0,937 & 15 & 0,347 & Normal \\
\hline & Kelompok Perlakuan 2 & 0,927 & 15 & 0,244 & Normal \\
\hline & Kelompok Kontrol & 0,893 & 15 & 0,074 & Normal \\
\hline \multirow[t]{3}{*}{ Postes agility } & Kelompok Perlakuan 1 & 0,957 & 15 & 0,638 & Normal \\
\hline & Kelompok Perlakuan 2 & 0,908 & 15 & 0,128 & Normal \\
\hline & Kelompok Kontrol & 0,903 & 15 & 0,106 & Normal \\
\hline
\end{tabular}

Berdasarkan Tabel 4 dapat dilihat bahwa seluruh data terdistribusi normal. Dengan hal ini maka uji prasyarat pertama telah terpenuhi. Selanjutnya dilakukan uji prasyarat kedua, yaitu pengujian homogenitas variansi. Uji homogenitas variansi memiliki tujuan untuk mengetahui apakah skor yang digunakan dalam penelitian memiliki varian yang homogen antar kelompok. Uji ini dilakukan sebagai prasyarat dalam pengujian analisis varian (Anava). Hasil pengujian ditunjukkan pada Tabel 5 sebagai berikut.

Tabel 5. Hasil Pengujian Homogenitas Variansi pada Masing-masing Variabel yang digunakan

\begin{tabular}{lcccc}
\hline Variabel & Levene Statistic & df1 & df2 & Sig. \\
\hline Power & 1,011 & 2 & 42 & 0,373 \\
Agility & 0,062 & 2 & 42 & 0,940 \\
\hline
\end{tabular}

Tabel 5 menunjukkan bahwa seluruh kelompok memiliki varian yang homogen. Dengan ini maka kedua syarat pengujian terpenuhi, maka jenis pengujian yang digunakan adalah uji parametrik.

Terdapat dua jenis latihan yang digunakan dalam penelitian ini. Pertama adalah icky shuffle dan yang kedua adalah hop scotch. Kedua jenis latihan diberikan pada kelompok yang berbeda. Pengujian pengaruh menggunakan paired sampel $t$ test. Hasil pengujian ditunjukkan pada Tabel 6 .

Tabel 6. Hasil Uji Pengaruh Perlakuan

Terhadap Power

\begin{tabular}{lccccc}
\hline Kelompok & Mean & SD & $\mathrm{t}$ & $\mathrm{df}$ & Sig \\
\hline $\begin{array}{l}\text { Kelompok } \\
\text { Perlakuan 1 }\end{array}$ & $-30,23$ & 18,99 & $-6,17$ & 14 & 0,000 \\
$\begin{array}{l}\text { Kelompok } \\
\text { Perlakuan 2 }\end{array}$ & $-21,58$ & 12,16 & $-6,87$ & 14 & 0,000 \\
\hline
\end{tabular}

Hasil perhitungan dengan menggunakan paired sampel t test diperoleh skor signifikansi kurang ari dari 0,05 (sigi<0,05). Hasil ini menunjukkan bahwa terdapat pengaruh yang diberikan dari dari kedua jenis latihan terhadap power.

Selain power, agility merupakan variabel yang diukur dalam penelitian. Untuk mengetahui ada tidaknya pengaruh yang diberikan oleh jenis latihan, maka diuji dengan menggunakan paired sampel t test. Hasil pengujian ditunjukkan pada Tabel 7 .

Tabel 7. Hasil Uji Pengaruh Perlakuan

Terhadap Agility

\begin{tabular}{|l:c:c:c:c:c} 
Kelompok & Mean & SD & $t$ & df & Sig \\
\hline KelompokPerlakuan 1 & 0,16 & 0,07 & 8,60 & 14 & 0,000 \\
\hline KelompokPerlakuan2 & 0,13 & 0,06 & 8,67 & 14 & 0,000 \\
\hline
\end{tabular}

Hasil perhitungan dengan menggunakan paired sampel t test diperoleh skor signifikansi kurang ari dari 0,05 (sig.<0,05). Hasil ini menunjukkan bahwa terdapat pengaruh yang diberikan dari dari kedua jenis latihan terhadap agility.

Analisis selanjutnya adalah mengetahui perbedaan pengaruh dari masingmasing perlakuan. Teknik yang digunakan untuk mengetahui ada tidaknya pengaruh yang diberikan jenis program latihan adalah anava. Selanjutnya dilakukan analisis pos hoc untuk mengetahui kelompok mana saja yang memiliki perbedaan pengaruh. Penelitian ini menggunakan tiga teknik, yaitu Tukey, LSD, dan Benferoni. Hasil pengujian Anava ditunjukkan pada Tabel 8 yang diikuti pos hoc pada Tabel 9.

Tabel 8. Analisis Varians Masing-masing Kelompok Perlakuan

\begin{tabular}{|c|c|c|c|c|c|}
\hline \multicolumn{2}{|c|}{ Variabel } & $\mathrm{df}$ & MS & F & Sig. \\
\hline \multirow[t]{3}{*}{ Power } & Between Groups & 2 & 23806,51 & 1,75 & 0,19 \\
\hline & Within Groups & 42 & 13634,42 & & \\
\hline & Total & 44 & & & \\
\hline \multirow[t]{3}{*}{ Aglity } & Between Groups & 2 & 0,10 & 0,12 & 0,89 \\
\hline & Within Groups & 42 & 0,84 & & \\
\hline & Total & 44 & & & \\
\hline
\end{tabular}

Hasil perhitungan Anava diperoleh signifikansi untuk power $=0,19$ dan signifikansi untuk agility $=0,89$. Nilai ini 
lebih besar daripada 0,05. Maka dapat ditarik kesimpulan terdapat perbedaan pengaruh pada kelompok perlakuan. Untuk mengetahui kelompok mana yang memberikan pengaruh yang berbeda, dilakukan uji pos hoc. Hasil analisis uji pos hoc ditunjukkan pada Tabel 9.

Tabel 9. Pos Hoc

\begin{tabular}{|c|c|c|c|c|c|c|}
\hline & Dependen & Variabl & & $\begin{array}{l}\text { Mean } \\
\text { Dif. } \\
\text { (I-J) }\end{array}$ & $\begin{array}{l}\text { Std. } \\
\text { Error }\end{array}$ & Sig. \\
\hline \multirow[t]{18}{*}{ Power } & Tukey & \multirow[t]{2}{*}{ Kel 1} & Kel 2 & $-75,40$ & 42,64 & 0,19 \\
\hline & \multirow[t]{5}{*}{ HSD } & & Kel 3 & $-60,01$ & 42,64 & 0,35 \\
\hline & & \multirow[t]{2}{*}{ Kel 2} & Kel 1 & 75,40 & 42,64 & 0,19 \\
\hline & & & Kel 3 & 15,38 & 42,64 & 0,93 \\
\hline & & \multirow[t]{2}{*}{ Kel 3} & Kel 1 & 60,01 & 42,64 & 0,35 \\
\hline & & & Kel 2 & $-15,38$ & 42,64 & 0,93 \\
\hline & \multirow[t]{6}{*}{ LSD } & \multirow[t]{2}{*}{ Kel 1} & Kel 2 & $-75,40$ & 42,64 & 0,08 \\
\hline & & & Kel 3 & $-60,01$ & 42,64 & 0,17 \\
\hline & & \multirow{2}{*}{ Kel 2} & Kel 1 & 75,40 & 42,64 & 0,08 \\
\hline & & & Kel 3 & 15,38 & 42,64 & 0,72 \\
\hline & & \multirow[t]{2}{*}{ Kel 3} & Kel 1 & 60,01 & 42,64 & 0,17 \\
\hline & & & Kel 2 & $-15,38$ & 42,64 & 0,72 \\
\hline & \multirow{6}{*}{$\begin{array}{l}\text { Bonfe } \\
\text { rroni }\end{array}$} & \multirow[t]{2}{*}{ Kel 1} & Kel 2 & $-75,40$ & 42,64 & 0,25 \\
\hline & & & Kel 3 & $-60,01$ & 42,64 & 0,50 \\
\hline & & \multirow[t]{2}{*}{ Kel 2} & Kel 1 & 75,40 & 42,64 & 0,25 \\
\hline & & & Kel 3 & 15,38 & 42,64 & 1,00 \\
\hline & & \multirow[t]{2}{*}{ Kel 3} & Kel 1 & 60,01 & 42,64 & 0,50 \\
\hline & & & Kel 2 & $-15,38$ & 42,64 & 1,00 \\
\hline \multirow[t]{18}{*}{ Agility } & Tukey & \multirow[t]{2}{*}{ Kel 1} & Kel 2 & $-0,10$ & 0,33 & 0,95 \\
\hline & HSD & & Kel 3 & $-0,16$ & 0,33 & 0,88 \\
\hline & & \multirow[t]{2}{*}{ Kel 2} & Kel 1 & 0,10 & 0,33 & 0,95 \\
\hline & & & Kel 3 & $-0,05$ & 0,33 & 0,99 \\
\hline & & \multirow[t]{2}{*}{ Kel 3} & Kel 1 & 0,16 & 0,33 & 0,88 \\
\hline & & & Kel 2 & 0,05 & 0,33 & 0,99 \\
\hline & \multirow[t]{6}{*}{ LSD } & \multirow[t]{2}{*}{ Kel 1} & Kel 2 & $-0,10$ & 0,33 & 0,76 \\
\hline & & & Kel 3 & $-0,16$ & 0,33 & 0,64 \\
\hline & & \multirow[t]{2}{*}{ Kel 2} & Kel 1 & 0,10 & 0,33 & 0,76 \\
\hline & & & Kel 3 & $-0,05$ & 0,33 & 0,87 \\
\hline & & \multirow[t]{2}{*}{ Kel 3} & Kel 1 & 0,16 & 0,33 & 0,64 \\
\hline & & & Kel 2 & 0,05 & 0,33 & 0,87 \\
\hline & \multirow{6}{*}{$\begin{array}{l}\text { Bonfe } \\
\text { rroni }\end{array}$} & \multirow[t]{2}{*}{ Kel 1} & Kel 2 & $-0,10$ & 0,33 & 1,00 \\
\hline & & & Kel 3 & $-0,16$ & 0,33 & 1,00 \\
\hline & & \multirow[t]{2}{*}{ Kel 2} & Kel 1 & 0,10 & 0,33 & 1,00 \\
\hline & & & Kel 3 & $-0,05$ & 0,33 & 1,00 \\
\hline & & \multirow[t]{2}{*}{ Kel 3} & Kel 1 & 0,16 & 0,33 & 1,00 \\
\hline & & & Kel 2 & 0,05 & 0,33 & 1,00 \\
\hline
\end{tabular}

Berdasarkan pengujian pos hoc pada Tabel 9 diperoleh nilai signifikansi yang lebih dari 0,05. Dari skor ini maka dapat disimpulkan bahwa masing-masing kelompok memberikan pengaruh yang berbeda terhadap power dan agility.

Latihan digunakan untuk mempersiapkan menghadapi kompetisi olahraga melalui sistem terencana dan sistematis (Venkatachalapathy, 2015). Untuk itu diperlukan sebuah latihan terstruktur dan terprogram dengan baik yang dikenal dengan istilah program latihan (Sukadiyanto, 2011).
Sesuai dengan hal tersebut, penelitian ini mencoba melakukan eksperimen terhadap dua bentuk program latihan pada sekelompok siswa di SMAN 5 Mataram. Subjek penelitian bukan merupakan atlet profesional yang terbiasa melakukan latihan rutin dan terprogram. Tujuan dari penelitian ini untuk mengetahui apakah kedua bentuk latihan memberikan pengaruh terhadap subjek penelitian. Selain itu diulas pula perbedaan pengaruh yang diberikan dari kedua bentuk latihan.

Jenis latihan yang digunakan dalam penelitian ini adalah ladder drill. Jenis latihan ladder drill baik jika digunakan untuk meningkatkan performa kaki dalam kelincahan, kecepatan, dan koordinasi (Tsivkin, 2011). Latihan ladder drill menggunakan bantuan alat menyerupai tangga. Atlet atau subjek dalam penelitian akan menggunakan objek berbentuk tangga tersebut untuk aktivitas berlari, melompat, dan meloncat dengan memanfaatkan kaki (Scrhirm, 2011). Seperti banyak diketahui bahwa berbagai macam aktivitas seperti berlari dan melompat dapat digunakan untuk meningkatkan power dan kelincahan (Chimera \& Kremer, 2016; Degens et al, 2019). Ladder drill sendiri memiliki banyak bentuk latihan yang dapat digunakan. Penelitian ini menggunakan dua jenis latihan, yaitu icky shuffle dan hop scotch.

Program latihan icky shuffle yang diberikan terhadap subjek penelitian dengan intensitas yang digunakan berada pada intensitas rendah antara 30\% - 60\% untuk mengoptimalkan power (Kusnanik dkk., 2011). Tiga set digunakan untuk intensitas rendah dengan waktu istirahat antara $2-3$ menit (Bompa, 2015). Program latihan ini diberikan kepada subjek penelitian selama delapan minggu dengan tiga kali pertama tiap minggu. Total penggunaan program latihan ini adalah 24 kali. Setelah dilakukan 24 kali penerapan program latihan icky shuffle, didapatkan hasil bahwa terdapat pengaruh yang signifikan terhadap kelincahan dan power pada subjek penelitian. Hasil ini didukung perhitungan SPSS menggunakan paired sampel $t$ test yang memperoleh Sig. = 
$0,000(\operatorname{Sig}<0,05)$ pada power dan Sig. $=0,000$ $($ Sig $<0,05)$ pada kelincahan. Berdasarkan hasil ini diketahui bahwa latihan icky shuffle mampu memberikan pengaruh yang signifikan terhadap power dan kekuatan otot tungkai.

Hasil ini didukung oleh penelitian Saputra (2019) yang melakukan penelitian dengan judul "Pelatihan agility ladder metode icky shuffle 4 repetisi 3 set terhadap peningkatan kelincahan gerak peserta ekstra kurikuler sepak bola SMP Negeri 2 Denpasar tahun 2019”. Penelitian ini menggunakan sampel penelitian sebanyak 24 siswa dengan usia 13 - 15 tahun. Program latihan yang digunakan adalah 4 repetisi 3 set. Hasil penelitian oleh Saputra (2019) menjelaskan bahwa terdapat pengaruh yang diberikan latihan ladder drill metode icky shuffle terhadap kelincahan siswa. Lebih lanjut, Dasilva (2016) mengatakan bahwa latihan ladder drill tipe icky shuffle secara signifikan mampu meningkatkan kelincahan seseorang. Dalam penelitiannya digunakan sampel sejumlah 15 orang. Aspek yang diukur dari penelitiannya adalah tentang kecepatan ditinjau dari kelincahan.

Kelincahan memang memiliki hubungan yang cukup erat dengan kecepatan. Kelincahan merupakan gabungan dari kecepatan dan koordinasi seseorang dalam melakukan sebuah aktivitas (Bompa \& Buzzichelli, 2015). Kusuma \& Kardiawan (2017) turut pula menguji pengaruh dari Icky shuffle terhadap kecepatan dan kelincahan. Dalam penelitiannya menggunakan 30 orang sebagai sampel. Uji yang digunakan untuk mengukur kelincahan adalah Illinois Agility Test. Hasil yang diperoleh dalam penelitian tersebut adalah terdapat pengaruh yang signifikan yang diberikan oleh latihan icky shuffle terhadap kelincahan.

Selain untuk menguji kelicahan, penelitian ini juga menguji pengaruhnya terhadap daya ledak (power) otot tungkai. Hasil penelitian menunjukkan bahwa terdapat pengaruh yang signifikan antara latihan iccky shuffle dan power otot tungkai. Hasil ini didukung oleh hasil perhitungan SPSS yang menunjukkan nilai signifikansi $=0,00$ pada pengujian pengaruh latihan icky shuffle terhadap power otot tungkai. Hasil penelitian oleh Pelamonia \& Harmono (2018) mendukung temuan penelitian ini. Mereka melakukan penelitian untuk menguji pengaruh dari latihan icky shuffle terhadap power dan kecepatan. Subjek yang digunakan adalah atlet perisai diri. Hasil penelitian menunjukkan bahwa latihan icky shuffle mampu meningkatkan power, namun tidak mampu meningkatkan kecepatan dari subjek penelitian. Hasil ini sesuai dengan pernyataan bahwa jenis latihan ladder drill mampu meningkatkan kemampuan keterampilan gerak (Reynolds, 2011). Sehingga mampu meningkatkan power dari otot tungkai.

Penelitian lebih lanjut menjelaskan bahwa icky shuffle tidak hanya dapat digunakan untuk memperbaiki power, kecepatan, dan kelincahan. Meng \& Lee (2014) melakukan penelitian tentang pengaruh latihan icky shuffle terhadap keseimbangan. Latihan dilakukan selama 4 Minggu dengan 3 kali pertemuan setiap Minggu. Subjek yang digunakan dalam penelitian ini adalah siswa laki-laki dari 18 sekolah. Hasil penelitian menunjukkan bahwa terdapat pengaruh latihan ladder drill icky shuffle terhadap keseimbangan anak. Namun dalam penelitian ini ditemukan bahwa tidak ada perbedaan pengaruh yang diberikan antara kelompok eksperimen dan kelompok kontrol.

Hasil dalam penelitian ini menemukan bahwa terdapat pengaruh yang diberikan program latihan hop scotch terhadap power dan kelincahan. Hasil ini didukung oleh perhitungan SPSS yang menunjukkan nilai Sig. $=0,000 \quad(<0,05)$. Program latihan ini diberikan bersamaan dengan program latihan icky shuffle, namun pada kelompok berbeda. Hop Scotch adalah salah satu bentuk tes ladder drill yang menyerupai permainan tradisional engklek. Untuk itu hopscoth lebih banyak digunakan dalam pengujian terhadap koordinasi. Perwitasari \& Isnaini (2016) meguji apalah bentuk permainan engklek (hop scotch) memberikan pengaruh terhadap motorik kasar anak. Uji yang digunakan untuk menguji tingkat motori kasar anak adalah Test 
Gross Motor Development (TGMD). Hasil pengujian menunjukkan bahwa terdapat pengaruh yang signifikan dari permainan engklek terhadap tingkat motorik kasar anak. Hop scotch merupakan jenis latihan yang tergolong ringan. Untuk itu biasanya latihan ini tidak dikerjakan secara sendiri. Diperlukan kombinasi dari jenis latihan lain untuk meningkatkan efektivitas hasil latihan. Pawar \& Borkar (2018) melakukan penelitian dengan judul effect of ladder drills training in female kabaddi players. Penelitian ini menggunakan semua bentuk latihan ladder drill untuk menguji kelincahan pada atlet semi profesional perempuan kabaddi. Terdapat 31 jenis latihan ladder drill yang digunakan selama kurun waktu 6 Minggu. Hasil penelitian menunjukkan bahwa terdapat pengaruh yang signifikan dalam program latihan yang diberikan kepada atlet semi profesional kabaddi. Seperti dikatakan sebelumnya, hopscotch memiliki pola gerakan seperti permainan tradisional engklek. Tujuan dari program latihan ini lebih utama untuk meningkatkan koordinasi otak. Namun dengan intensitas yang tepat, ternyata ditemukan bahwa latihan hopscotch memiliki pengaruh yang signifikan terhadap otot tungkai.

Hasil dalam penelitian ini menunjukkan bahwa terdapat pengaruh yang signifikan pada pemberian program latihan icky shuffle dan hop scotch. Lebih lanjut diuji apakah terdapat perbedaan pengaruh yang diberikan pada program latihan tersebut. Hasil pengujian menggunakan anava satu jalur menemukan bahwa terdapat perbedaan pengaruh yang diberikan oleh pemberian program latihan icky shuffle dan hop scotch. Hasil ini didukung oleh hasil perhitungan pada aspek power Sig $=0,19$ dan pada aspek kelincahan Sig $=0,89$. Kedua nilai ini lebih besar daripada 0,05 sehingga dapat disimpulkan bahwa terdapat perbedaan pengaruh yang diberikan oleh program latihan.

Icky shuffle dan hop scotch merupakan jenis latihan ladder drill yang memanfaatkan gambar menyerupai tangga dalam proses pelaksanaannya. Telah banyak dilakukan penelitian pada program latihan icky shuffle yang mampu meningkatkan power dan kelincahan (Kusuma \& Kardiawan, 2017; Pelamonia, \& Harmono, 2018; Saputra, 2019). Sedangkan untuk latihan hopscotch masih sedikit yang meneliti tentang hubungannya dengan power dan kelincahan. Program latihan hop scotch lebih banyak digunakan untuk model penelitian lain yang berhubungan tentang konsentrasi anak.

Salah satunya adalah Lucht \& Heidig (2013) yang mencoba menggunakan model hop scotch dalam penguasaan vocabulari bahasa Inggris pada sekelompok siswa SMP. Mereka memandang bahwa hop scotch identik dengan permainan anak-anak sehingga cocok jika diberikan pada anak-anak. Hasil dari penelitian tersebut menemukan bahwa hop scotch dapat digunakan sebagai bahan pendamping proses pembelajaran di kelas. Selain Lucht \& Heidig (2013) masih banyak pula peneliti yang menggunakan hop scotch sebagai program latihan non fisik. Tujuannya adalah memanfaatkan pola permainan untuk meningkatkan konsentrasi anak. Icky shuffle dan hop scotch dan merupakan jenis program latihan yang menggunakan media berbentuk tangga dalam pelaksanaannya. Gerakan yang dilakukan juga cukup sederhana, yaitu melompat dan berlari melalui tangga dengan pola tertentu. Penelitian ini dilakukan dengan menggunakan pola tangga yang dibentuk pada sebuah lapangan. Hal yang sedikit berbeda dilakukan oleh Lei, Cheng, \& Lee (2018). Mereka mencoba melakukan latihan ladder drill icky shuffle dan hop scotch dengan menggunakan media Virtual Reality (VR). Penelitian ini memiliki tujuan untuk menguji apakah latihan ladder drill bisa digunakan menggunakan virtual reality. Dari penelitian ini mereka menemukan bahwa virtual reality dapat digunakan sebagai media dalam melakukan latihan ladder drill. Pola pengembangan alat seperti yang dilakukan oleh Lei et al., (2018) mungkin dilakukan jika program latihan dan tujuan dari latihan bukanlah untuk meningkatkan fisik. Program latihan untuk meningkatkan fisik cenderung memiliki intensitas yang tinggi. Penggunaan virtual reality bukanlah hal yang tepat pada 
kondisi seperti ini. Namun jika tujuan program latihan adalah sebagai media pembelajaran seperti Lucht dan Heidig (2013), maka virtual reality dapat digunakan dengan lebih baik.

\section{KESIMPULAN}

Berdasarkan hasil penelitian dapat disimpulkan; a) terdapat pengaruh yang signifikan latihan Icky Shuffle terhadap peningkatan kelincahan dan power otot tungkai, b) terdapat pengaruh yang signifikan latihan Hop Scotch terhadap peningkatan kelincahan dan power otot tungkai, dan c) terdapat perbedaan pengaruh yang signifikan antara latihan Icky Shuffle dan Hop Scotch terhadap peningkatan kelincahan dan power otot tungkai. Beberapa saran dalam penelitian ini, yaitu perlu penelitian lanjutan mengenai latihan Icky Shuffle dan Hop Scotch dengan kondisi sampel yang berbeda. Bagi para pelatih, agar dalam menyusun program latihan harus memperhatikan karakteristik setiap atlet sehingga atlet mampu melaksanakan program latihan tersebut dengan baik dan lancar, dan yang paling utama adalah latihan Icky Shuffle dan Hop Scotch dapat direkomendasikan dan diterapkan dalam program latihan untuk meningkatkan kelincahan dan power otot tungkai.

\section{DAFTAR PUSTAKA}

Ambarukmi, D. H., Pasurney, P., Sidik, D. Z., Irianto, D. P., Dewanti, R. A., Sunyoto., Sulistiyanto, D., \& Harahap, M. Y. (2007). Pelatihan Pelatih Fisik Level 1. Jakarta: Kemenpora.

Arikunto, S. (2010). Prosedur Penelitian. Jakarta: PT. Renika Cipta.

Arjunan, R. (2015). Effect of Speed, Agility and Quickness (S. A. Q) Training on Selected Physical Fitness Variables Among School Soccer Players. International Journal of Research in Humanities, Arts and Literature (IMPACT: IJRHAL). Vol. 3, Issue 10.

Atanasković, Andrija \& Martin Georgiev. (2013). The Impact of Plyometric Training on the Explosive Power of the Lower Extremities of Handball Player. Sport - Science \& Practice. Vol. 3, no.1.

Bompa, and Haff, G, (2009). Theory and Methodology of Training. United States : Human Kinetics.

Bompa, Tudor O \& Carlo Buzzichelli. (2015). Periodization Training for Sports. Third Edition. United States : Human Kinetics.

Brown, Lee E., \& Vance A. Ferrigno. (2005). Training for Speed, Agility, and Quickness. 2nd ed. United States: Human Kinetics.

Chandrakumar, N. \& C. Ramesh. (2015). Effect of ladder drill and SAQ training on speed and agility among sports club badminton players. International Journal of Applied Research. 1(12): 527-529.

Clark, Micheal A., Scott C. Lucett, \& Brian G. Sutton. (2012). NASM Essentials of Personal Fitness Training. Fourth Edition. Philadelpia: Lippincott Williams \& Wilkins, a Wolters Kluwer business.

Dawes, Jay \& Mark Roonzen. (2012). Developing Agility and Quickness. Australia: Human Kinetics.

Gamble, P. (2012). "Training For Sports, Speed, and Agility An Evidence-Based Approach". Prepress Projects Ltd, Perth, UK.

Haci, M. S. (2014). Relationships between acceleration, agility, and jumping ability in female volleyball players. European Journal of Experimental Biology. 4(1), 303-308.

Haff, Gregory G., \& N. Travis Triplett. (2016). Essentials of Strength Training and Conditioning. United States: Human Kinetics.

Haff, Gregory G., \& Sophia Nimphius. (2012). Training Principles for Power. Strength and Conditioning Journal. Volume 34, Nomor 6.

Harsono. (2015). Kepelatihan Olahraga Teori dan Metodologi. Bandung : PT Remaja Rosdakarya. 
Horička, Pavol., Ján Hianik, \& Jaromír Šimonek. (2014). The Relationship Between Speed Factors and Agility in Sport Games. Journal of Human Sport \& Exercise. Volume 9. Issue 1.

Jamil, Syarulniza Abdul, Nurhani Aziz, \& Lim Boon Hooi. (2015). Effects Of Ladder Drills Training On Agility Performance. International Journal of Health, Physical Education and Computer Science in Sports. Volume No.17, No.1.

Jovanic, Mario, Goran Sporis, Darija Omrcen, \& Fredi Fiorentini. (2011). Effects of Speed, Agility, Quickness Training Method on Power Performance In Elite Soccer Players. Journal of Strength and Conditioning Research. Volume 25. Number 5.

Joyce, David, \& Daniel Lewindon. (2014). High-performance training for sports. United States: Human Kinetics.

Kenney, Larry, Jack H. Wilmore, \& David L. Costill. (2012). Physiology of Sport and Exercise. Fifth Edition. United States: Human Kinetics.

Khatri, Akash, \& V.Vallimurugan. (2015). Effect of Ladder Training on Selected Psychological Variables among KhoKho Players. International Journal of Recent Research and Applied Studies. Volume 2,Issue 4(1).

Kusnanik, N.W., Nasution, J., dan Hartono, S. (2011). Dasar-dasar Fisiologi Olahraga. Unesa: Unesa University Press.

Lee, Buddy. (2010). Jump Rope Training. 2nd ed. United States: Human Kinetics.

Maksum, Ali. (2012). Metodologi Penelitian dalam Olahraga. Surabaya: Unesa University Press.

Raghuram, R., \& I. Devi Vara Prasad. (2016). Analysis of the Changes in Selected Speed and Power Parameters in Response to Assisted and Resisted Sprint Training among Male Sprinters. International Journal of Recent Research and Applied Studies. Volume 3, Issue 10.
Rajendran, K. (2016). Effect of Ladder Training on Agility among College level Football Players. International Journal of Recent Research and Applied Studies. Volume 3, Issue 4 (23).

Rajkumar, R., \& K.Divya. (2016). Effect of SAQ Training on Selected Physical Responses Among College Men Students. Indian Journal of Applied Research. Volume:6, Issue:8.

Ratamess, Nicholas. (2012). ACSM's Foundations of Strength Training and Conditioning. Indianapolis. Lippincott Williams \& Wilkins.

Roesdiyanto dan Setyo Budiwanto, (2008). "Dasar-Dasar Kepelatihan Olahraga". Malang: Laboratorium Ilmu Keolahragaan Universitas Negeri Malang.

Sahin, Haci Murat. (2014). Relationships Between Acceleration, Agility, and Jumping Ability in Female Volleyball Players. European Journal of Experimental Biology: 4(1):303-308.

Schirm, Matthew. (2011). http://www.livestrong.com. Diakses tanggal 10 Januari 2017.

Sethu, S. (2014). Comparison of Plyometric Training and Ladder Training on Sprinting Speed, Vertical Explosive Power and Agility. International Journal of Recent Research and Applied Studies. Volume 1, Issue 1(15).

Sharma, Sandeep, \& Mahesh Singh Dhapola. (2015). Effect of Speed, Agility, Quickness (SAQ) Training Programme on Selected Physical Fitness Variables and Performance Ability in Basketball University Players. International Educational EJournal. Volume-IV, Issue-III.

Sporis, Goran, Zoran Milanović, Nebojša Trajković and Aleksandar Joksimović. (2010). Correlation Between Speed, Agility and Quickness (SAQ) In Elite Young Soccer Players. Acta Kinesiologica: 2: 36-41. 
Srinivasan, M. (2013). Influence of Conventional Training Programme Combined With Ladder Training on Selected Physical Fitness and Skill Performance Variables of College Level Badminton Players. International Journal of Behavioral Social and Movement Sciences. Vol.02, Issue03.

Sucharitha, B.S., Reddy, A.V., and Madhavi, K. (2014). "Effectiveness Of Plyometric Training On Anaerobic Power And Agility In Female Badminton Players". International Journal of Pharmaceutical Research and Bio-Scienc. ISSN:22778713, Volume 3 No 4.pp 754-761.

Sukadiyanto dan Muluk, D. (2011). Pengantar Teori dan Metodologi Melatih Fisik. Bandung: Lubuk Agung.

Suresh, A. \& S. Bevinson Perinbaraj. (2016). Effect of SAQ Training Associated with Speed Training on Agility Explosive Power and Speed among Engineering College Sports Persons. International Journal of Recent Research and Applied Studies. Volume 3, Issue 6 (12).

Taheri, Eskandar, Asghar Nikseresht, \& Ebrahim Khoshnam. (2014). The Effect of 8 Weeks of Plyometric and Resistance Training on Agility, Speed and Explosive Power in Soccer Players. European Journal of Experimental Biology. 4(1): 383-386.

Tsivkin, Troman. (2011). http: //www.sportfitness-advisor.com. di unduh tanggal 10 Januari 2018.

Unesa. (2015). Buku Pedoman Program Pascasarjana Universitas Negeri Surabaya. Surabaya: PPS Universitas Negeri Surabaya.

Vallimurugan, V. and Vincent, J.P. (2012). Effect of SAQ Training On Selected Physical Fitness Parameters og Men Football Palyers. International Journal of Advanted and Inovation Research. Volume 1, Issue 2.
Venkatachalapathy R. (2015). Effect of Circuit Training Programme on Speed and Agility. International Journal of Recent Research and Applied Studies. ISSN: 2349-4891

Widiastuti, (2011). Tes dan Pengukuran Olahraga. Jakarta: PT. Bumi Jaya.

Winarno, M.E. (2011). Metodologi Penelitian dalam Pendidikan Jasmani. Malang: Media Cakrawala Utama Press. 